Discussion Papers

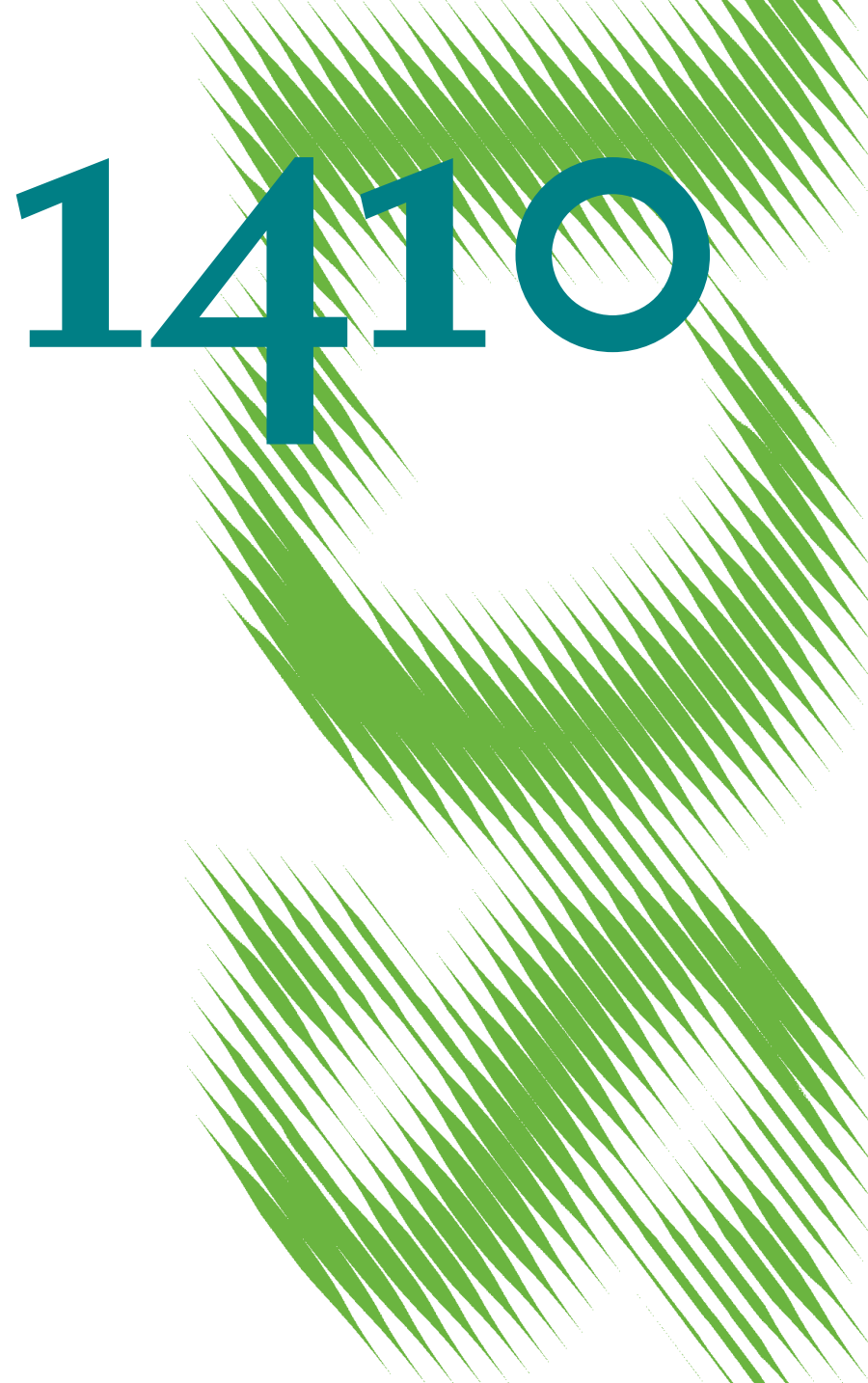

Small Might be Beautiful, But Bigger Performs Better:

Scale Economies in "Green«

Refurbishments of Apartment Housing 
Opinions expressed in this paper are those of the author(s) and do not necessarily reflect views of the institute.

IMPRESSUM

(C) DIW Berlin, 2014

DIW Berlin

German Institute for Economic Research

Mohrenstr. 58

10117 Berlin

Tel. +49 (30) $89789-0$

Fax +49 (30) $89789-200$

http://www.diw.de

ISSN electronic edition 1619-4535

Papers can be downloaded free of charge from the DIW Berlin website:

http://www.diw.de/discussionpapers

Discussion Papers of DIW Berlin are indexed in RePEc and SSRN:

http://ideas.repec.org/s/diw/diwwpp.html

http://www.ssrn.com/link/DIW-Berlin-German-Inst-Econ-Res.html 


\title{
Small might be beautiful, but bigger performs better: scale economies in "green" refurbishments of apartment housing
}

\author{
Claus Michelsen ${ }^{\mathrm{a}, *}$, Sebastian Rosenschon ${ }^{\mathrm{b}}$, Christian Schulz ${ }^{\mathrm{b}}$ \\ ${ }^{a}$ Deutsches Institut für Wirtschaftsforschung, Mohrenstraße 58, 10117 Berlin, Germany. \\ ${ }^{b}$ Halle Institute for Economic Research, Kleine Märkerstr. 8, 06108 Halle, Germany.
}

\begin{abstract}
The energy efficiency of the residential housing stock plays a key role in strategies to mitigate climate change and global warming. In this context, it is frequently argued that private investment and the quality of thermal upgrades is too low in the light of the challenges faced and the potential energy cost savings. While many authors address the potential barriers for investors to increase energy efficiency, studies on the capabilities different investors have to reduce energy requirements of their property are scarce. This study investigates potential advantages of housing company's size, i.e. economies of scale, economies of scope and institutional learning in thermal upgrades of residential housing. Based on unique data on energy consumption in 102,307 apartment houses in Germany, we present new evidence for advantages and disadvantages of housing company's size in "green" retrofitting projects. Our estimations show, that large housing companies outperform private landlords by far in high effort refurbishment projects. In contrast, private landlords appear to have advantages in low effort, incremental refurbishment activities. The results offer new options for policy makers to refine the support schemes towards a low carbon housing stock.
\end{abstract}

Keywords: "green" real estate, energy efficiency, refurbishment, economies of scale, economies of scope JEL Codes: R31, R32, Q48

\footnotetext{
*Email: cmichelsen@diw.de, Phone:+49 (0)30 89789 458; Corresponding author.
} 


\section{Introduction}

Global warming is one major challenge for present and future energy and climate policy. Therefore, many countries are seeking to restructure their energy supply systems and energy demand patterns. In this context, the housing stock plays an important role since it accounts for a large share of energy demand - for example in Germany, residential energy needs sum up to roughly one third of primary energy consumption. In this context, space heating and cooling is one factor of high relevance. In European countries about two thirds of the domestic energy demand is used for indoor climate (OECD, 2003). Current policies towards a higher energy efficiency of the housing stock particularly focus on regulation by "Building Energy Codes" (Annunziata et al., 2013; Iwaro and Mwasha, 2010; Jacobsen and Kotchen, 2013) and financial support schemes like the "Green Deal" in the UK or the programs provided by the public German bank KfW. However, it is frequently argued, that new instruments are needed, because existing policies do not attract sufficient investment (see, e.g., Dowson et al., 2012) to implement for example the "Nearly Zero-Energy Buildings" standard, as targeted by the European Commission by 2020 (European Commission, 2012).

Many studies address the different barriers for "green" retrofits and construction, including (among others) the "landlord-tenant-dilemma" (see, e.g., Rehdanz, 2007; Schleich and Gruber, 2008), insufficient willingness to pay for energy efficiency on real estate markets (see, e.g., Hyland et al., 2013), uncertainty about real energy cost savings (see, e.g., Metcalf and Hassett, 1999) or behavioral aspects, norms and attitudes, that prevent homeowners from investing in "green" technologies (see, e.g., Nair et al., 2010). Research, however, has not focused significantly on understanding the capabilities of different types of investors and the subsequent opportunities these differences offer policymakers in designing strategies for less energy consuming economies. One option can be to exhaust the potentials of scale economies in construction and refurbishment. This approach is not entirely new. As a response to housing supply shortages in the aftermath of the industrialization, standardized, functional design - as, for example, promoted by the German "Bauhaus" movement in the early $20^{\text {th }}$ century - was used in large scale construction projects to reduce the costs of construction and to increase housing standards. Today, this can also be a promising approach to increase the energy efficiency in the rental housing sector. In many countries, a substantial share of the housing stock is owned by professional investors, like 
real estate investment trusts (REITs), or co-operative housing companies that could benefit from scale economies in "green" retrofitting projects.

It is well established in the literature that larger construction enterprises and housing companies benefit from firm size in the provision of housing services (Fleming, 1965, 1967; Herzog, 1963; Maisel, 1953; Stevens, 1975, see,). According to Myers (2008) and Eccles (1981), larger firms might also have advantages due to the process of organizational learning and economies of scope. Indeed, empirical literature indicates that larger firms outperform their smaller competitors in terms of greater profitability (Benjamin et al., 2007), higher rental income, and more professional portfolio management (Hardin et al., 2009). On average, larger companies also provide higher levels of housing quality, as pointed out by Malpezzi and Shilling (2000). Overall this also indicates the ability of large housing firms - compared to private landlords - to improve the energy efficiency of their buildings at lower average costs. However, empirical evidence for this presumption is missing. In this paper, we assess the impact of firm size on the outcomes of green thermal upgrades by comparing three groups of investors: private landlords, small housing providers and large housing companies. For the empirical analysis we use a unique sample of "energy performance certificates" for 102,307 apartment houses in Germany. ${ }^{1}$

The remainder of our paper is structured as follows: in the next section we develop a simplified theoretical framework. Based on the arguments found in the literature, we then motivate our expectations about the effects of housing companies' size in the context of energy efficiency investments. The third section describes the data and methods employed and the underlying empirical strategy. Based on our estimations, we find strong evidence for advantages of larger housing firms over private landlords in the provision of energy efficient housing services. We conclude, that investors attributes and abilities should also be considered in future policies toward higher energy efficiency of the housing stock.

\section{Motivation and hypothesis}

\subsection{A simplified concept of investment decisions}

The empirical finding that larger companies outperform smaller firms (Benjamin et al., 2007; Hardin et al., 2009) can, on the one hand, be explained

\footnotetext{
${ }^{1}$ We are grateful to ista Germany $\mathrm{GmbH}$ for providing the data.
} 
by cost advantages in housing service production. On the other hand, higher and more stable revenues from renting out the property can also cause the differences observed. Regardless which aspect dominates, both should - when the yield would be maximized if marginal costs equal marginal revenuesimpact the decision on the optimal level of energy efficiency provided to tenants, when building or retrofitting a home.

Theoretically, this can be formulated as follows: let each housing firm's revenue, $R(e)$, be a function of the level of energy efficiency, $e$, and an additional effect of a professional portfolio management, a parameter $b>0$, where $R^{\prime}(e) \geq 0, R^{\prime \prime}(e) \leq 0$, and $\lim _{e \rightarrow 0} R^{\prime}(e)=\infty$. Let the cost of extending $e$ be $\frac{1}{s} C(e)$, where $C^{\prime}(e)>0$ and $C^{\prime \prime}(e)>0$. The coefficient $s>0$ refers to the firm size. Thus a housing firm's profit function, $\pi$, is given by

$$
\pi=b R(e)-\frac{1}{s} C(e) .
$$

A maximization approach for $\pi$ over eleads to the following determination equation:

$$
0=b R^{\prime}(e)-\frac{1}{s} C^{\prime}(e) .
$$

Let the solution to (2) be denoted by $e^{*}$. Because $R^{\prime \prime}(e)-\frac{1}{s} C^{\prime \prime}\left(e^{*}\right)<0, e^{*}$ constitutes a unique solution. An increasing housing firm size should, in this setup, positively impact the optimal level of energy efficiency due to cost advantages. Totally differentiating (2) with respect to $e$ and $s$ leads to

$$
\frac{d e^{*}}{d s}=\frac{\frac{1}{s^{2}} C^{\prime}\left(e^{*}\right)}{b R^{\prime \prime}\left(e^{*}\right) \frac{1}{s^{2}} C^{\prime \prime}\left(e^{*}\right)}>0,
$$

since $C^{\prime}(e)>0$ and $b R^{\prime \prime}(e)<0$. Moreover, it can be expected that professional portfolio management, i.e. lower losses due to vacancy and potentially higher rental income from the signalling effect of "good" housing quality, results in a higher overall energy efficiency. Totally differentiating (2) with respect to $e$ and $b$, we get

$$
\frac{d e^{*}}{d b}=\frac{-R^{\prime}\left(e^{*}\right)}{b R^{\prime \prime}\left(e^{*}\right)-\frac{1}{s} \cdot C^{\prime \prime}\left(e^{*}\right)}>0 .
$$

An illustration for both aspects is shown in Figure 1, where two housing companies of different sizes $\left(s_{1}, s_{2}\right)$ face the optimization problem of energy 
Figure 1: optimal investment by housing companies $s_{1}$ and $s_{2}$

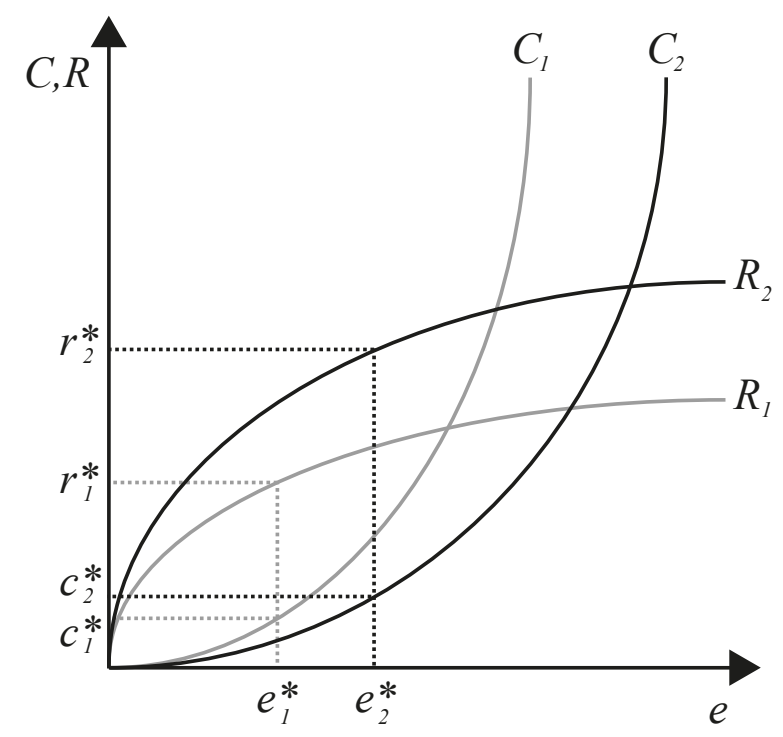

efficiency investment, decreasing marginal revenues and increasing marginal costs of housing service production: the steeper construction cost curve $\left(C_{1}\right)$ refers to the smaller company $\left(s_{1}\right)$, while $C_{2}$ refers to the larger company $\left(s_{2}\right)$, which has comparative advantages in housing service production. Since in buy-to-let markets, landlords do not directly profit from energy (cost) conservation, tenants' willingness to pay for energy efficiency improvements limits the revenues. Assuming the level as being largely exogenously determined while there might be a small difference due to signalling and professional portfolio management, ${ }^{2}$ maximizing the yield of investment should lead to different levels of energy efficiency $e^{*}$. Thus, given $s_{1}<s_{2}$ and $b_{1}<b_{2}$, it follows that $e_{1}^{*}<e_{2}^{*}$. In other words: larger firms produce higher levels of energy efficiency in green retrofitting projects.

\footnotetext{
${ }^{2}$ It is implicitly assumed that firm size does not affect revenues from investment beyond the aspect mentioned, even though there is reason to believe that monopolistic power or a higher concentration of larger firms might have an impact on the level of rents in the respective market (Arnott, 1995). Moreover, it is assumed that both types of firms calculate with an identical economic lifetime of the investment and identical tax treatments.
} 


\subsection{Related literature}

The existing literature mainly focuses on new construction projects (see, e.g., Fleming, 1965, 1967; Herzog, 1963; Stevens, 1975), thus highlighting the activities of real estate development companies. However, the same arguments should also apply in the refurbishment context: in this case private landlords and housing companies act as producers of housing services (comparable to real estate developers). They decide about the level of housing services produced by maintenance, refurbishment or new construction efforts (Arnott et al., 1983). Thus, we expect that those attributes that are already found to affect real estate developers' cost functions will also hold for companies and private landlords that are mainly concerned with renting flats. In particular, the following aspects are discussed in previous studies.

\section{Economies of scale}

It is frequently argued that larger companies benefit from economies of scale in refurbishment or new construction projects. In contrast to private landlords or smaller firms, mostly investing in only a single or few buildings, larger companies in many cases develop several buildings at one site or several buildings of a more or less identical type, which can, as Stevens (1975) demonstrates for multi-family housing in the US, reduce average construction and refurbishment costs. Sources are identified in:

- recurring project characteristics;

- adoption of standardized construction processes; techniques and materials (Buzzelli and Harris, 2006; Gann, 1996; Kinzy, 1992),

- quantity discount for purchasing materials and services;

- higher flexibility in labour use (Maisel, 1953; Stevens, 1975);

- access to financial resources (Somerville, 1999) and

- lower capital costs (Ambrose et al., 2005; Bogdon and Ling, 1998).

Substantially similar arguments are presented for the overall construction sector (Ball, 2006). 


\section{Economies of scope and institutional learning}

Apart from the aspects related to economies of scale, it is reasonable to assume that investors gain experience in refurbishment projects over time. Presumably, due to the durability of housing, private landlords build and refurbish a dwelling once in their lifetime and thus have a "single attempt" to achieve a desired energy efficiency standard. A company's knowledge on how to combine different techniques and materials can be repeatedly used for other refurbishment projects and thus should enter the production function of refurbishment cost reduction, because this could allow firms to vertically integrate real estate development tasks such as planning, architectural services or supervision.

As Coase (1937) introduced in his seminal paper on transaction costs, vertical integration of processes and services allows larger firms to reduce costs of production. In the real estate refurbishment context, this might be the case when different stages of project development can be pursued within one real estate company. It is reasonable to assume that vertical integration of, for example, project planning is rational when a company is sufficiently large and the knowledge can be repeatedly used within the firm. In contrast, smaller firms and private investors have to buy these services at market prices, which could lead to higher average costs of refurbishment projects. But vertical integration is not a necessary condition to realize advantages in transaction cost reduction. As Eccles (1981) proposes, Williamsonian transaction costs can be reduced by subcontracting between project developers/real estate companies and other firms (see, Eccles, 1981; Somerville, 1999; Williamson, 1979). It is argued that "quasi-firms" (Eccles, 1981) reduce costs by a higher degree of trust between contractual partners accompanied by a higher frequency of transactions and higher transaction-specific investments. This is more likely to be the case when real estate companies own a larger housing portfolio and refurbishment or renovation activities can be repeated.

\section{Effects on revenue}

Beyond production costs, the size of housing companies might play an additional role in the energy efficiency context: Benjamin et al. (2007) show that branding has a positive impact on rents. Given that branding is costly and pays off in the long run, large housing companies should benefit almost exclusively from such strategy. Nevertheless branding is not the predominant strategy in apartment housing markets (see, Hardin et al., 2009, p. 286) but signaling quality to customers is important. In this context, signaling by 
energy efficiency may be an attractive substitute for a brand, since climate change is prominently discussed in politics and in the media. Moreover, it is found in empirical studies that energy efficiency positively affects house prices and rents (Brounen and Kok, 2011; Hyland et al., 2013). Given that energy efficiency is a costly housing attribute, a strategy of large companies toward long-run lettability (compared to their competitors) could trigger them to play their cost advantage against smaller competitors and to refurbish their property at a significantly higher level (Ben-Shahar, 2004; Benjamin et al., 2007).

\section{Research questions and empirical strategy}

Against the background of the theoretical considerations and the arguments presented in the previous literature, we address the potential advantages of the firm size in "green" retrofitting projects. More specifically, our empirical strategy aims to identify, whether

1. housing company's size generally has an effect on the energy efficiency of refurbished houses,

2. if the energy efficiency of refurbished homes increases with firm size; and

3. if differences between firm-specific refurbishment outcomes increases with project size.

\subsection{Empirical strategy}

To answer these questions, we use a unique dataset of apartment buildings in Germany and their real energy demand. We identify the expected effects of firm size using information on the energy efficiency of the respective building, information on the firm size of the owner and indicators for the refurbishment effort undertaken in the past. We then regress the natural logarithm of the energy coefficient per square metre $(E C)^{3}$ of a building $(i)$ on (self-reported) refurbishment effort $\left(R_{j}\right.$ where $j=1 \ldots 5$, the sum of refurbished parts of a building) and a set of dummy variables indicating whether the home is owned

\footnotetext{
${ }^{3}$ To improve the readability of our results, we multiplied $\ln (E C)$ by -1 indicating that estimated positive semi-elasticities can be interpreted as percentage increases in energy efficiency.
} 
by a private landlord $\left(F^{P}\right)$, a small housing company $\left(F^{S}\right)$, the base group) or large housing companies $\left(F^{L}\right.$;see Table 2$)$, which are defined in Section 3.2. The landlords are grouped by the number of owned flats. Finally, to identify the effects of project and firm size, we introduce an interaction term of $R \times F$. Moreover, we introduce several control variables $(X)$ to our model, including: the building's age (age in years by age-classes), its size (number of flats by size-classes) and its location (planning regions),

$$
\begin{array}{r}
-\ln (E C)_{i}=\alpha+\gamma_{P} F_{i}^{P}+\gamma_{L} F_{i}^{L} \\
+\sum_{j=1}^{5}\left(\lambda_{j} R_{i, j}+\lambda_{P, j} R_{i, j} \times F_{i}^{O}+\lambda_{L, j} R_{i, j} \times F_{i}^{L}\right)+\beta X_{i}+v_{i},
\end{array}
$$

where $\alpha, \gamma, \lambda, \beta$ are coefficients and $v$ is the i.i.d. error component.

The first question is addressed by the coefficients $\lambda_{P}$ and $\lambda_{L}$. We expect them to be jointly significantly different from zero (Wald-test), meaning that compared to small housing companies, private landlords and large housing companies produce different levels of energy efficiency $\left(\lambda_{P} \neq 0\right.$ and $\left.\lambda_{L} \neq 0\right)$ even when it is simultaneously controlled for unobserved differences of the non-refurbished housing stock $\left(\gamma_{P}, \gamma_{L}\right)$.

In the second question, it is assumed that refurbishment outcomes increase with firm size. In our setup, we expect the coefficient $\lambda_{L}$ to be significantly larger or equal to zero, indicating that for each level of refurbishment effort, larger housing companies' refurbishment outcome is at least equal to the outcome of small housing companies. The opposite relation should hold for private landlords: the coefficient $\lambda_{P}$ is expected to be exclusively smaller than or at least equal to zero. We test these relations using a t-test.

The third question can be answered by comparing the difference in the marginal effects of the coefficients $\lambda$. Since we expect to find increasing returns to companies' size by refurbishment effort, the difference between the marginal effects of $\lambda_{L}$ and $\lambda_{P}$ should increase with refurbishment effort (the difference to the base category should increase by refurbishment effort). In non-technical words, we test the slope of firm type specific energy-efficiency increases against each other.

\subsection{Data and variables}

In the empirical analysis, data provided by ista Germany GmbH - a leading energy billing service provider in Germany, covering about $15 \%$ of the 
overall apartment housing stock - is used. The data contains information from energy bills as well as from energy certificates. Both data sources contain housing-specific information, which is used to compute the variables needed for the econometric model. Further, we use "climatic parameters" provided by the German Weather Service (DWD) to account for spatial differences of climate and weather in the period of observation (2008).

\section{Energy coefficients}

The energy coefficients $(E C)$ for each building $(i)$ are calculated based on an established procedure introduced by the Association of German Engineers (Verein Deutscher Ingenieure (VDI)) according to its guideline, VDI-3807. As a basis, the raw energy measures $(B)$ for each fuel type $(F)$ (e.g. oil in litres, natural gas in kilowatt-hours $(k W h))$ for space heating are multiplied by their "heat value" $(H)$ to derive consistent energy consumption measures in $k W h$ per period $(t)$. These measures are adjusted by regional "climatic parameters" $(C P)$, which are available for 8,400 postal-code districts $(r)$ and standardized by living space of the dwelling in square-metres $\left(m^{2}\right)^{4}$.

$$
E C_{i, t}=\frac{\left(B_{i, t} \times H_{F} \times C P_{r, t}\right)}{m^{2}}
$$

$E C$ is a measure for the annual energy requirement of a building per square metre. In our sample of 102,307 buildings, we find energy coefficients ranging from 30.13 to $399.97 \mathrm{kWh} / \mathrm{m}^{2}$ (see Table 1). On average, apartment houses in Germany require $136 \mathrm{kWh} / \mathrm{m}^{2}$ for space heating annually; this is consistent with other studies relying on an identical or a comparable information (see, e.g., Greller et al., 2010; Michelsen, 2009).

Table 1: Descriptive statistics of EC

\begin{tabular}{lccccc}
\hline Variable & Obs. & Mean & St.Dev. & Min & Max \\
\hline$E C$ & 102,307 & 136.01 & 49.22 & 30.13 & 399.97 \\
\hline
\end{tabular}

\footnotetext{
${ }^{4}$ The procedure adjusts the energy requirements to the German city of Würzburg in the year 2002. For a more detailed description of the climatic parameters see www.dwd.de/klimafaktoren.
} 


\section{Housing companies' size}

Size is measured by counting flats per housing company. In Germany, multi-family housing accounts for approximately $50 \%$ of the overall housing stock - roughly $75 \%$ refer to the rental sector. Almost twothirds of the market for rental flats is owned by private landlords; one sixth is offered by private housing companies. The remaining stock is let by public housing companies, housing co-operatives and religious organizations (see, Veser et al., 2007). Further, it can be observed that the German buy-to-let market is attracting growing attention of global real-estate investors (see, Hesse and Preckwinkel, 2009).

In the literature, there is no consistent classification of firm size and characteristics apart from legal definitions (see, BBSR, 2010; Veser et al., 2007). Since we do not have any information about the companies' legal status, we rely on a classification based on the number of flats owned by a company to identify whether it acts as a large housing company, small housing company or as private landlord. As summarized in Table 2, we define "private landlords" as investors owning fewer than 21 flats. "Small housing companies" are defined in a range from 21 up to 1,000 flats. On average, this type of company owns 4.9 houses. "Large housing companies" are understood as being owners of more than 1,000 flats. ${ }^{5}$ In contrast to single-unit owners, we expect the latter type of housing companies to be large enough to run their business exclusively from rental income.

Table 2: Descriptive statistics on housing companies' size

\begin{tabular}{lccc}
\hline Variable & $\begin{array}{c}\text { Private } \\
\text { landlords } \\
<21 \text { flats }\end{array}$ & $\begin{array}{c}\text { Small housing } \\
\text { companies } \\
\text { 21-1,000 flats }\end{array}$ & $\begin{array}{c}\text { Large housing } \\
\text { companies } \\
>1,000 \text { flats }\end{array}$ \\
\hline No. of firms & 33,753 & 8,005 & 1,464 \\
No. of houses owned & 37,106 & 38,984 & 26,217 \\
\% of houses in sample & $36.3 \%$ & $38.10 \%$ & $25.6 \%$ \\
Av. no. of houses in sample & 1.1 & 4.9 & 17.9 \\
\hline
\end{tabular}

\footnotetext{
${ }^{5}$ In this context, we face a measurement problem: exact information on firm size is not available for all companies. Large housing companies are for example classified by e.g. "owning $>5,000$ flats" or "owning $>10,000$ flats". For this reason, we have to rely on a dummy classification rather than introducing a metric measure for firm size.
} 


\section{Refurbishment effort}

Information on the refurbishment effort relies on self-reported measures of landlords. The introduction of mandatory "energy certificates" for each house for sale or for rent, based on European Union regulation (European Commission, 2002), necessitates that real estate owners provide at least minimum information on the energy efficiency of construction components and their refurbishment efforts respectively. Our database, therefore, contains information on the period of time when a specific part of a building was refurbished: for example, it is identified whether the windows of a house have been refurbished or replaced within the past 15 years, more than 15 years ago, if they are non-refurbished or if it is unknown. This information is available for the five, from the energy efficiency perspective, most important components of a house: roof, facade, windows, basement ceiling and heating system. Based on this information, we derived a set of dummy variables indicating the overall refurbishment effort. This is measured by the number of refurbished construction parts. We created 10 interaction terms by multiplying these variables with dummy variables indicating whether the building is owned by a "private landlord" or a "large housing company" respectively. In this context, refurbishment effort of small housing companies is the base category. Table 3 summarizes frequencies of refurbishment by firm type.

Overall, we observe that nearly $11 \%$ of houses in our sample are completely non-refurbished, which means that none of the parts of the building mentioned have undergone major refurbishment "in the past 15 years". The information was mainly gathered in the years 2008/2009 - thus the lower bound of refurbishment is the year 1993. About $8.2 \%$ of houses in our sample are completely refurbished, while about $6.6 \%$ are close to being completely refurbished (one major part missing). 
Table 3: Refurbishment effort by company types

\begin{tabular}{lcccc}
\hline $\begin{array}{l}\text { Refurbishment } \\
\text { effort }\end{array}$ & $\begin{array}{c}\text { Private } \\
\text { landlords }\end{array}$ & $\begin{array}{c}\text { Small } \\
\text { housing } \\
\text { companies }\end{array}$ & $\begin{array}{c}\text { Large } \\
\text { housing } \\
\text { companies }\end{array}$ & $\begin{array}{c}\text { Overall \% } \\
\text { of refur- } \\
\text { bishment }\end{array}$ \\
\hline $\begin{array}{l}\text { Non-refurbished } \\
\text { (0 parts) }\end{array}$ & 3,431 & 4,526 & 2,900 & $10.90 \%$ \\
$\begin{array}{l}\text { Very low effort } \\
\text { (1 part) }\end{array}$ & 7,363 & 5,295 & 3,291 & $15.60 \%$ \\
$\begin{array}{l}\text { Low effort } \\
\text { (2 parts) }\end{array}$ & 7,017 & 3,214 & 1,816 & $11.80 \%$ \\
$\begin{array}{l}\text { Medium effort } \\
\text { (3 parts) }\end{array}$ & 4,802 & 2,275 & 1,501 & $8.40 \%$ \\
$\begin{array}{l}\text { High effort } \\
\text { (4 parts) }\end{array}$ & 2,969 & 2,025 & 1,804 & $6.60 \%$ \\
$\begin{array}{l}\text { Full refurbishment } \\
\text { (5 parts) }\end{array}$ & 2,148 & 3,283 & 2,932 & $8.40 \%$ \\
$\begin{array}{l}\text { Other } \\
\text { combination* }\end{array}$ & 3,038 & 5,865 & 5,601 & $14.50 \%$ \\
Built after 1993 & 6,338 & 12,501 & 6,372 & $24.60 \%$ \\
\hline Total & 37,106 & 38,984 & 26,217 & $100.0 \%$ \\
\hline
\end{tabular}

*Other combinations can be houses where none of the parts were refurbished within the past 15 years while at least one construction component was replaced more than 15 years ago and others were reported as being unknown.

\section{Control Variables}

In addition to the aforementioned variables, we include several control variables in our model. Definitions and descriptive statistics are given in Table 4. First, we include dummies indicating the spatial location of the house. This should capture possible differences in market conditions, as proposed by several researchers working on "green" real estate investment and its impact on house prices (see, e.g., Hyland et al., 2013; Kok et al., 2012).

Moreover, there is evidence for variation in construction materials and techniques over time and space which have to be considered when refurbishment is analysed (Costa and Kahn, 2011; Klauß et al., 2009). Thus, apart from the regional component captured in the dummies' for planning regions (ROR), we include measures for the age of housing. To account for age cohort specific housing attributes, we differentiate between vintage classes of buildings and interact them by their respective age in years. Moreover, the 
regional variables capture possible heterogeneity of differing housing market and socio-economic conditions that may affect the level of refurbishment and energy consumption.

Moreover, there is evidence for differences in the refurbishment outcome according to the building's size (e.g. due to differences in the ratio of living space to the exterior surface of a building, see, e.g., Leth-Petersen and Togeby (2001)). Finally, we introduce dummy variables if the refurbishment status of a specific part of the house is reported "unknown". In total, our model consists of 141 regressors, including a constant. For clarity, we present selected results in the following subsection. ${ }^{6}$

Table 4: Control variables: definitions and descriptive statistics

\begin{tabular}{|c|c|c|c|c|c|c|}
\hline Variable & Definition & Obs. & Mean & Sd. & Min & $\operatorname{Max}$ \\
\hline \multicolumn{7}{|l|}{ Size } \\
\hline Class 2 to 6 & Size of building; & 47,219 & 4.5 & 1.21 & 2 & 6 \\
\hline Class 7 to 12 & no. of flats by & 29,027 & 9.1 & 1.72 & 7 & 12 \\
\hline Class 13 to 21 & housing size classes & 11,986 & 16.4 & 2.41 & 13 & 21 \\
\hline Class $>21$ & & 14,075 & 44.9 & 3.5 & 22 & 763 \\
\hline \multicolumn{7}{|l|}{ Age } \\
\hline Before 1919 & Age of building & 12,116 & 111.4 & 30.5 & 90 & 408 \\
\hline 1919- 1948 & in years by vintage & 7,149 & 77.5 & 7.3 & 60 & 89 \\
\hline 1949- 1957 & classes (as of 2008) & 6,056 & 54.3 & 2.5 & 51 & 59 \\
\hline 1958- 1968 & & 14,868 & 44.7 & 3.1 & 40 & 50 \\
\hline 1969- 1978 & & 16,096 & 35 & 2.6 & 30 & 39 \\
\hline 1979- 1983 & & 7,360 & 26.8 & 1.4 & 25 & 29 \\
\hline 1984- 1992 & & 13,451 & 19.5 & 2.9 & 16 & 24 \\
\hline 1993- 2006 & & 25,211 & 11.6 & 2.9 & 2 & 15 \\
\hline \multicolumn{7}{|c|}{ Refurbishment status unknown } \\
\hline Roof & $\begin{array}{l}\text { Dummy variables } \\
(0,1)\end{array}$ & 102,307 & 0.3 & 0.46 & 0 & 1 \\
\hline Facade & $\begin{array}{l}\text { indicating whether } \\
\text { the }\end{array}$ & 102,307 & 0.31 & 0.46 & 0 & 1 \\
\hline Windows & $\begin{array}{l}\text { refurbishment } \\
\text { status is }\end{array}$ & 102,307 & 0.29 & 0.45 & 0 & 1 \\
\hline Basement ceiling & $\begin{array}{l}\text { known (base } \\
\text { category) }\end{array}$ & 102,307 & 0.36 & 0.48 & 0 & 1 \\
\hline Heating system & or unknown (1) & 102,307 & 0.27 & 0.44 & 0 & 1 \\
\hline
\end{tabular}

\footnotetext{
${ }^{6}$ The results of the fully specified model are available by the authors upon request.
} 


\section{Results}

We estimated the model specified in Equation 5 using ordinary least squares (OLS). The results are presented in Table 5 and 9. Since the BreuschPagan test strongly rejects homoscedasticity $(F(140,102,166)=6.92)$, we employ Huber-White corrected standard errors. Overall, our model has significant explanatory power for roughly $30 \%\left(R^{2}=0.2999\right)$ of total variation.

Table 5: Model diagnostics

\begin{tabular}{ccc}
\hline $\mathbf{N}$ & $R^{2}$ & $\mathbf{F}$-test \\
\hline 102,307 & 0.2995 & $F(140 ; 102,166)=312.02^{* * *}$ \\
\hline
\end{tabular}

First we refer to the coefficients of the average energy-efficiency gains for different refurbishment projects (see Table 6). The coefficients for refurbishment effort show the expected positive sign and significance at the $1 \%$ level. Semi-elasticities can be interpreted as average energy-efficiency gains from refurbishment. As depicted in Figure 2 and Table 6, energy conservation of projects with very low and low effort is comparatively small. On average, a $2.1 \%$ increase for very low effort and a $4.7 \%$ increase of the energy efficiency for low effort projects can be observed. In contrast, full refurbishment leads to an increase of energy efficiency of approximately $26.2 \%$. Generally, as expected, efficiency gains increase with project size. More over, based on our empirical analysis, we can draw four specific findings regarding the impact of housing companies' size on refurbishment outcomes and the overall energy efficiency of buildings. 
Table 6: Estimation results: effects of refurbishment compared to small housing companies

\begin{tabular}{|c|c|c|c|c|c|}
\hline \multicolumn{2}{|c|}{ Variable } & \multicolumn{2}{|l|}{ Coef. } & \multirow{2}{*}{$\frac{\mathbf{t}}{4.10}$} & \multirow{2}{*}{$\frac{\mathbf{S E}}{0.0051}$} \\
\hline Average effects of & very low effort & 0.0209 & $* * *$ & & \\
\hline & low effort & 0.0470 & $* * *$ & 7.60 & 0.0062 \\
\hline & medium effort & 0.1228 & $* * *$ & 16.67 & 0.0074 \\
\hline & high effort & 0.1786 & $* * *$ & 22.49 & 0.0079 \\
\hline & full refurbishment & 0.2616 & $* * *$ & 37.32 & 0.0070 \\
\hline \multirow[t]{5}{*}{ Private landlords $\times$} & very low effort & 0.0102 & & 1.56 & 0.0065 \\
\hline & low effort & -0.0045 & & -0.61 & 0.0074 \\
\hline & medium effort & -0.0481 & $* * *$ & -5.48 & 0.0088 \\
\hline & high effort & -0.0728 & $* * *$ & -7.33 & 0.0099 \\
\hline & full refurbishment & -0.1023 & $* * *$ & -9.99 & 0.0102 \\
\hline \multirow[t]{8}{*}{ Large housing company $\times$} & very low effort & -0.0144 & $*$ & -1.95 & 0.0074 \\
\hline & low effort & 0.0042 & & 0.45 & 0.0093 \\
\hline & medium effort & 0.0830 & $* * *$ & 7.62 & 0.0109 \\
\hline & high effort & 0.1330 & $* * *$ & 12.39 & 0.0107 \\
\hline & full refurbishment & 0.1380 & $* * *$ & 15.75 & 0.0088 \\
\hline & Single-unit owner & 0.0474 & $* * *$ & 13.04 & 0.0036 \\
\hline & Large housing company & -0.0015 & & -0.45 & 0.0034 \\
\hline & Constant & -5.1489 & $* * *$ & -301.42 & 0.0171 \\
\hline
\end{tabular}

***,*indicate significance at 1\%, $10 \%$ levels of confidence; Huber-White standard errors.

Finding 1: Company size affects refurbishment outcome

We find evidence for a company-specific influence on the energy-efficiency of refurbished apartment buildings. Particularly we find that housing company's firm size positively impacts on refurbishment outcomes. We expected to find the coefficients for the interaction terms of firm types and refurbishment effort to be significantly different from zero. To confirm this outcome, we jointly tested for differences between coefficients using the Wald-test (see Table 7), which strongly rejects the hypothesis of equality. 
Table 7: Marginal effects; Wald-test $H_{0}$ : marginal effect $=0$

\begin{tabular}{lccrc}
\hline & Marg. effect & SE & $\chi^{2}$ & \\
\hline Private landlords & & & & \\
very low effort & $03.11 \%$ & 0.0050 & 38.57 & $* * *$ \\
low effort & $04.25 \%$ & 0.0051 & 68.59 & $* * *$ \\
medium effort & $07.47 \%$ & 0.0059 & 160.53 & $* * *$ \\
high effort & $10.58 \%$ & 0.0071 & 223.38 & $* * *$ \\
full refurbishment & $15.93 \%$ & 0.0087 & 338.45 & $* * *$ \\
\hline Small housing companies & & & & \\
very low effort & $02.09 \%$ & 0.0051 & 16.85 & $* * *$ \\
low effort & $04.70 \%$ & 0.0062 & 57.73 & $* * *$ \\
medium effort & $12.28 \%$ & 0.0074 & 278.05 & $* * *$ \\
high effort & $17.86 \%$ & 0.0079 & 505.71 & $* * *$ \\
full refurbishment & $26.16 \%$ & 0,0070 & 1392.73 & $* * *$ \\
\hline Large housing companies & & & & \\
very low effort & $00.65 \%$ & 0.0061 & 1.15 & \\
low effort & $05.12 \%$ & 0.0077 & 44.29 & $* * *$ \\
medium effort & $20.58 \%$ & 0.0088 & 544.17 & $* * *$ \\
high effort & $31.15 \%$ & 0.0085 & 1340.16 & $* * *$ \\
full refurbishment & $39.96 \%$ & 0.0071 & 3133.38 & $* * *$ \\
\hline Joint & & & 4674.89 & $* * *$ \\
\hline & & & & \\
\hline & & & & \\
& & & &
\end{tabular}

*** indicate significance at $1 \%$ level of confidence.

Finding 2: Larger housing companies (mostly) produce higher energy effciency

Moreover, we expected to find positive coefficients or at least no differences (insignificant coefficients), for the interactions of large housing companies and refurbishment effort compared to the base category (small housing companies $)^{7}$. This would indicate that refurbishment outcomes increase with firm size. Indeed, we observe the expected positive signs for medium effort to full refurbishment projects, while the energy efficiency gains of low effort projects do not differ compared with small housing companies (see table 6). However, in contrast to our expectations, the coefficient for very low effort projects is negative at the $10 \%$ level of confidence. This indicates that larger housing companies obviously face diseconomies of scale for these types

\footnotetext{
${ }^{7}$ Negative or insignificant coefficients are expected for private landlords.
} 
of refurbishment projects. Additionally, the Wald-test (see Table 7) in this context indicates that buildings that underwent very low effort refurbishment by large housing companies do not have a higher energy efficiency in comparison to non-refurbished dwellings (the marginal effect does not significantly differ from zero).

Figure 2: Energy efficiency gains by refurbishment effort and company size

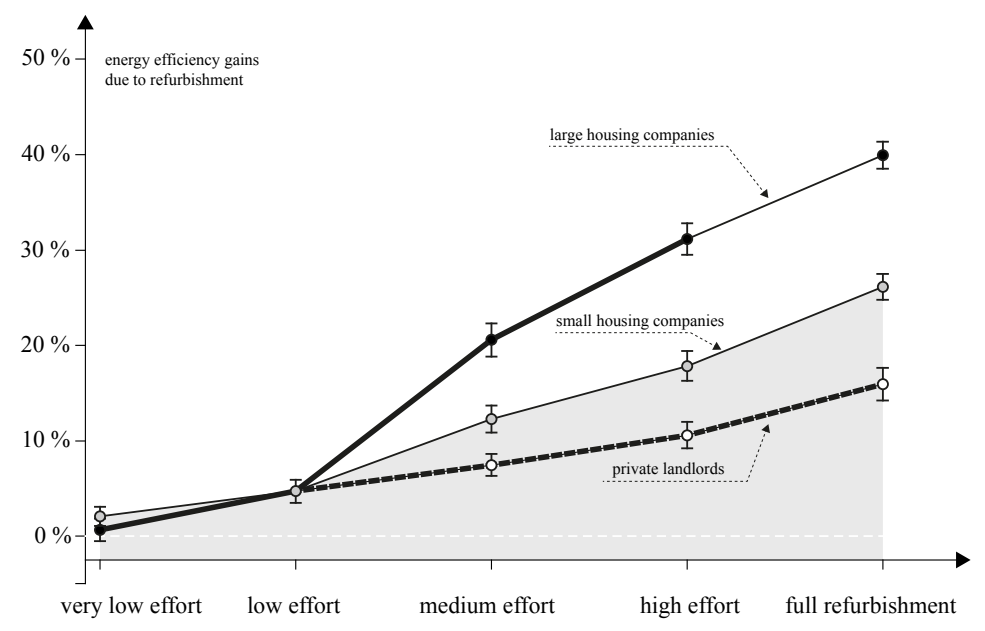

Whiskers represent 95\% confidence bands; Insignificant coefficients are not reported. Bold lines indicate significantly deviating slopes in energy efficiency increases compared to the base category.

The opposite is expected for private landlords: while differences compared to the base category cannot be observed for very low and low effort projects, private landlords' medium, high and full refurbishment efforts produce significantly less energy-efficiency. For full refurbishment, we estimated an accumulated average efficiency gain of $15.93 \%$, which is clearly below the outcome of large housing companies (39.96\%). Similar results can be observed for high (31.16\% vs. $10.58 \%)$ and medium effort (20.58\% vs. $7.47 \%)$ refurbishment. To summarize, advantages of the firm size can be observed for projects of medium to full refurbishment. No advantages or disadvantages to scale respectively can be observed for low and very low effort. 
Finding 3: Larger housing companies (mostly) benefit from increasing returns to scale by project size

The third finding relates to increasing differences between company types by refurbishment effort. As one can see (Table 7, Table 8 and Figure 2), the difference of the marginal effects increases by project size. We conclude that large housing companies benefit from advantages of firm size, particularly in very low to high effort projects. Small housing companies significantly underperform large housing companies in thermal upgrades. This is particularly the case for the energy efficiency gains between low and full refurbishment projects. While only small firm-size specific variation is observable in small projects, the difference for full refurbishment accumulates up to $24.03 \%$ (high effort: $20.58 \%$; medium effort: $13.11 \%$ ) between single-unit owners and large housing companies.

Table 8: Wald-test for differences in energy efficiency increases $(\Delta)$ by refurbishment effort and company size

\begin{tabular}{rcrrr}
\hline & Dif. & SE & $\chi^{2}$ & \\
\hline$\Delta$ Private landlords vs. $\Delta$ small & & & & \\
housing companies & & & & \\
$\Delta$ Non-refurbished to very low effort & 0.0102 & 0.0065 & 2.43 & \\
$\Delta$ Very low effort to low effort & -0.0146 & 0.0085 & 2.97 & $*$ \\
$\Delta$ Low effort to medium effort & -0.0437 & 0.0103 & 17.97 & $* * *$ \\
$\Delta$ Medium effort to high effort & -0.0247 & 0.0122 & 4.06 & $* *$ \\
$\Delta$ High effort to Full refurbishment & -0.0296 & 0.0133 & 4.93 & $* *$ \\
\hline$\Delta$ Large housing companies vs. & & & & \\
$\Delta$ small housing companies & & & & \\
$\Delta$ Non-refurbished to very low effort & $-0,0144$ & 0.0074 & 3.78 & $*$ \\
$\Delta$ Very low effort to low effort & 0,0186 & 0.0110 & 2.91 & $*$ \\
$\Delta$ Low effort to medium effort & 0,0788 & 0.0135 & 34.03 & $* * *$ \\
$\Delta$ Medium effort to high effort & 0,0499 & 0.0144 & 11.97 & $* * *$ \\
$\Delta$ High effort to Full refurbishment & 0,0050 & 0.0129 & 0.15 & \\
\hline Joint Test & & & 1041.52 & $* * *$ \\
\hline
\end{tabular}

$* * *, * *, *$ indicate significance at $1 \%, 5 \%$ and $10 \%$ level of confidence; differences indicate deviation from the base group (small housing companies). 
Finding 4: Overall, private landlords own "better" low quality housing, while large housing companies produce higher levels of energy efficiency in the medium to high quality segment

When comparing the overall energy efficiency (by including firm specific level effects), the disadvantages of private landlords are partly offset by a slightly higher housing quality of private landlords' non-refurbished homes. Overall, the level of energy efficiency is higher in private landlords' nonrefurbished, very low and low effort refurbished houses. In contrast, the overall energy efficiency is highest in medium effort to full refurbished homes of large housing companies (see figure 3 and table 9).

Figure 3: Overall energy efficiency by refurbishment effort and company size

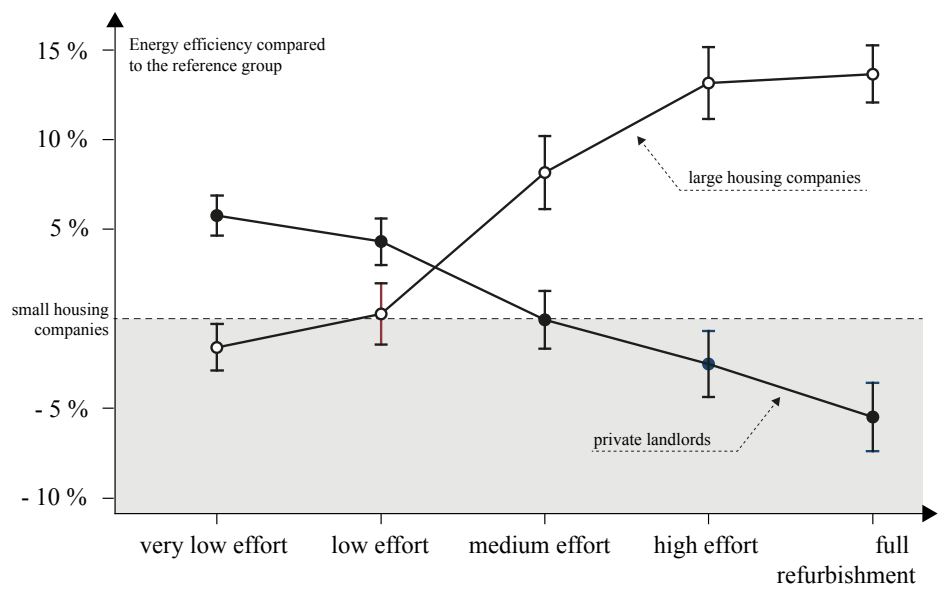

Whiskers represent 95\% confidence bands; normalized to housing quality of small housing companies. 
Table 9: Wald-test for differences in overall energy efficiency by refurbishment effort and company size

\begin{tabular}{rrrrr}
\hline & $\begin{array}{r}\text { marginal } \\
\text { effect }\end{array}$ & SE & $\chi^{2}$ \\
\hline Private landlords vs. small & & & \\
housing companies & & & \\
Non-refurbished & 4.74 & 0.0036 & 169.93 & $* * *$ \\
Very low effort & 5.76 & 0.0057 & 103.64 & $* * *$ \\
Low effort & 4.30 & 0.0066 & 42.04 & $* * *$ \\
Medium effort & 0.67 & 0.0082 & 0.01 & \\
High effort & -2.54 & 0.0094 & 7.28 & $* * *$ \\
Full refurbishment & -5.50 & 0.0097 & 31.99 & $* * *$ \\
\hline Large housing companies vs. & & & & \\
small housing companies & & & & \\
Non-refurbished & -0.15 & 0,0034 & 0.20 & \\
Very low effort & -1.59 & 0,0066 & 5.74 & $* *$ \\
Low effort & 0.27 & 0,0088 & 0.10 & \\
Medium effort & 8.15 & 0,0104 & 61.30 & $* * *$ \\
High effort & 13.14 & 0,0103 & 164.55 & $* * *$ \\
Full refurbishment & 13.64 & 0,0082 & 280.09 & $* * *$ \\
\hline Joint Test & & & 1245.9 & $* * *$ \\
\hline
\end{tabular}

$* * *, * *$ indicate significance at $1 \%$ and $5 \%$ level of confidence; differences indicate deviation from the base group (small housing companies).

The control variables show the expected signs for size and age, as proposed in the literature (see, Brounen et al., 2012; Greller et al., 2010; LethPetersen and Togeby, 2001; Michelsen and Müller-Michelsen, 2010; Schröder et al., 2009). Further, we find significantly lower energy coefficients for new dwellings built after 1993, which is in line with our expectations. Moreover, spatial differences are found to be present. Most of the dummy variables for planning regions show up significantly, indicating an influence of regional (market) conditions today and in history. However, this should also be subject to further research. 
Table 10: Results for the control variables

\begin{tabular}{|c|c|c|c|c|c|}
\hline Variable & & Coef. & & t-value & SE \\
\hline \multirow{5}{*}{$\begin{array}{r}\text { Unknown refurbishment } \\
\text { status of }\end{array}$} & roof & 0.0079 & & 1.63 & 0.0049 \\
\hline & facade & -0.0245 & $* * *$ & -5.04 & 0.0049 \\
\hline & windows & 0.0019 & & 0.42 & 0.0045 \\
\hline & basement ceiling & 0.0173 & $* * *$ & 4.40 & 0.0039 \\
\hline & heating system & 0.0277 & $* * *$ & 6.53 & 0.0042 \\
\hline \multirow[t]{4}{*}{ Size class } & class 3- 6 flats & base & & & \\
\hline & class 7 - 12 flats & 0.0207 & $*$ & 1.81 & 0.0115 \\
\hline & class $13-21$ flats & 0.0346 & & 1.58 & 0.0219 \\
\hline & class $>21$ & 0.2155 & $* * *$ & 27.57 & 0.0078 \\
\hline \multirow{4}{*}{ Size $\times$} & Size & 0.0122 & $* * *$ & 9.47 & 0.0013 \\
\hline & class 7 - 12 flats & -0.0019 & & -1.14 & 0.0016 \\
\hline & class $13-21$ flats & -0.0052 & $* * *$ & -2.87 & 0.0018 \\
\hline & class $>21$ & -0.0120 & $* * *$ & -9.28 & 0.0013 \\
\hline \multirow[t]{8}{*}{ Vintage class } & before 1919 & base & & & \\
\hline & 1919- 1948 & 0.1054 & $* *$ & 2.52 & 0.0418 \\
\hline & 1949- 1957 & -0.1675 & $*$ & -1.84 & 0.0910 \\
\hline & 1958- 1968 & 0.1237 & $* * *$ & 3.21 & 0.0385 \\
\hline & 1969- 1978 & 0.2062 & $* * *$ & 5.95 & 0.0347 \\
\hline & 1979-1983 & 0.4287 & $* * *$ & 5.88 & 0.0729 \\
\hline & $1984-1993$ & 0.3443 & $* * *$ & 15.66 & 0.0220 \\
\hline & $1994-2006$ & 0.9814 & $* * *$ & 66.43 & 0.0148 \\
\hline \multirow{8}{*}{ Age $\times$} & Age & 0.0003 & $* * *$ & 2.65 & 0.0001 \\
\hline & 1919- 1948 & -0.0013 & $* *$ & -2.41 & 0.0005 \\
\hline & 1949- 1957 & 0.0038 & $* *$ & 2.30 & 0.0017 \\
\hline & 1958- 1968 & -0.0013 & & -1.55 & 0.0008 \\
\hline & 1969- 1978 & -0.0029 & $* * *$ & -3.09 & 0.0009 \\
\hline & 1979- 1983 & -0.0102 & $* * *$ & -3.81 & 0.0027 \\
\hline & 1984- 1993 & -0.0066 & $* * *$ & -7.07 & 0.0009 \\
\hline & 1994- 2006 & -0.0476 & $* * *$ & -65.73 & 0.0007 \\
\hline
\end{tabular}

$* * *, * *$ and $* *$ indicate significance at $1 \%, 5 \%$ and $10 \%$ level of confidence; Huber-White robust standard errors.

\section{Conclusions}

In this paper we address the relationship between housing companies' size and the energy efficiency of refurbished apartment buildings. Motivated 
by production theory arguments (i.e. economies of scale and economies of scope), we expected energy efficiency to differ between three types of housing companies (single-unit owner, small housing companies and large housing companies). In line with the previous literature on scale economies in the construction sector, our findings suggest advantages of larger firms in refurbishments for higher energy efficiency. Particularly, our empirical findings lead us to three main conclusions, which are new aspects added to the existing literature around energy efficiency investments and housing supply:

i) Housing companies' size is an important predictor of energy efficiency. Refurbished apartment houses owned by large firms require substantially less heating energy than properties owned by small housing companies and private landlords. Moreover, energy efficiency increase with firm size, which lets us conclude that there exist the assumed effects of scale in refurbishment projects. For example, in completely refurbished apartment houses, the energy efficiency of property owned by large housing companies is $\approx 14 \%$ higher, compared to houses owned by small housing companies. In contrast, private landlords face disadvantages in energy efficiency compared to small housing companies of approximately $5.5 \%$ and $\approx 19 \%$ in comparison to large housing companies respectively.

ii) Advantages diminish as refurbishment efforts decrease and even turn into the opposite in projects where houses are incrementally refurbished (very low effort). This might be explained by several reasons: first, there might be differences in the maintenance effort between private and professional landlords. In many cases, private landlords live in or close to their rental property. This might reduce the so called "rental externality," which says that insecurity about tenants' utilization of the dwelling creates incentives for landlords to under maintain their property (Henderson and Ioannides, 1983; Iwata and Yamaga, 2008). Landlords might be more familiar with tenants behavior if they are frequently in touch. Additionally, if people are more familiar with the attributes of their property (due to spatial proximity or owner-occupation), they might be more effective at identifying small vulnerabilities and in fixing those with low refurbishment effort. In contrast, if large housing companies undertake low effort refurbishment, their fixed costs might be higher (e.g. if they maintain in house planning departments), which ceteris paribus reduces the budget for construction material (the thermal quality of construction parts). 
iii) Even after full refurbishment (under the conditions of the past fifteen years) energy conservation did not even approximately match the politically defined energy conservation targets - this is particularly true for private landlords but also holds for large housing companies.

For policy makers, these findings have substantial implications. First, if the target of a low carbon economy should be achieved, substantially greater investment is needed. Moreover, our results imply that the effectiveness of investment is different between types of landlords. This implies that support schemes should also consider this aspect. Thereby it depends on the desired outcome of the policy-for instance, one strategy could be to create specific incentives for large housing companies to invest in energy efficiency in advance, before the economic life time of previous investments has expired. This can be achieved, for example, by creating tax incentives or higher deductions for previous investments. Another option could be to increase financial support for private landlords in order to outweigh disadvantages of the firm size. A valid option could also be to create incentives for private landlords in one neighborhood to develop integrated refurbishment concepts for their property and thereby to benefit from scale economies.

Unfortunately, our results do not allow us to draw conclusions about the exact drivers of the observed differences, which creates avenues for further research. First, it would be interesting to disentangle the effects of size and to explicitly measure, for example, the impact of experience in energy efficiency retrofits. Second, it would be challenging to estimate real cost functions for energy efficiency investments by different types of housing companies. Finally, it could be a worthwhile exercise to estimate the effects energy conservation has on the time on market when a dwelling is offered for rent and if there are firm specific differences that could explain the presented findings in greater detail. 


\section{References}

Ambrose, B. W., Highfield, M. J., Linneman, P. D., 2005. Real Estate and Economies of Scale: The Case of REITs. Real Estate Economics 33 (2), $323-350$.

Annunziata, E., Frey, M., Rizzi, F., 2013. Towards nearly zero-energy buildings: The state-of-art of national regulations in Europe. Energy ,in Press.

Arnott, R., Davidson, R., Pines, D., 1983. Housing Quality, Maintenance and Rehabilitation. Review of Economic Studies 50 (3), 467-94.

Ball, M., 2006. Markets \& institutions in real estate \& construction. WileyBlackwell, Oxford.

BBSR, 2010. Energetic renewal in large housing estates. Tech. Rep. BBSROnline-Publikation, Nr. 05/2010, Bonn.

Ben-Shahar, D., 2004. Productive Signaling Equilibria and OverMaintenance: An Application to Real Estate Markets. Journal of Real Estate Finance and Economics 28 (2/3), 255-271.

Benjamin, J. D., Chinloy, P., Hardin, W. G. I., 2007. Institutional-grade properties: Performance and ownership. Journal of Real Estate Research 29 (3), 219-240.

Bogdon, A., Ling, D., 1998. The effects of property, owner, location, and tenant characteristics on multifamily profitability. Journal of Housing Research 9 (2), 285-316.

Brounen, D., Kok, N., 2011. On the economics of energy labels in the housing market. Journal of Environmental Economics and Management 62 (2), 166-179.

Brounen, D., Kok, N., Quigley, J. M., 2012. Residential energy use and conservation: Economics and demographics. European Economic Review $56(5), 931-945$.

Buzzelli, M., Harris, R., 2006. Cities as the Industrial Districts of Housebuilding. International Journal of Urban and Regional Research 30 (4), 894-917. 
Coase, R., 1937. The Nature of the Firm. Economica 4 (16), 386-405.

Costa, D. L., Kahn, M. E., 2011. Electricity consumption and durable housing: understanding cohort effects. American Economic Review: Papers \& Proceedings 101 (3), 88-92.

Dowson, M., Poole, A., Harrison, D., Susman, G., 2012. Domestic uk retrofit challenge: Barriers, incentives and current performance leading into the green deal. Energy Policy 50, 294-305.

Eccles, R. G., 1981. The quasifirm in the construction industry. Journal of Economic Behavior \& Organization 2 (4), 335-357.

European Commission, 2002. Directive 2002/91/EC of the European Parliament and of the Council of 16 December 2002 on the energy performance of buildings. Official Journal of the European Communities.

European Commission, 2012. Directive 2012/27/eu of the european parliament and of the council of 25 october 2012 on energy efficiency, amending directives 2009/125/ec and 2010/30/ec and repealing directives 2004/8/ec and 2006/32/ec. Official Journal of the European Union 315, 1-56.

Fleming, M. C., 1965. Costs and Prices in the Northern Ireland Construction Industry 1954-64. The Journal of Industrial Economics 14 (1), 42-54.

Fleming, M. C., 1967. Conventional Housebuilding and the Scale of Operations: a Study of Prices. Bulletin of the Oxford University Institute of Economics \& Statistics 29 (2), 109-137.

Gann, D., 1996. Construction as a manufacturing process? Similarities and differences between industrialized housing and car production in Japan. Construction Management and Economics 14 (5), 437-450.

Greller, M., Schröder, F., Hundt, V., Mundry, B., Papert, O., 2010. Universelle Energiekennzahlen für Deutschland - Teil 2: Verbrauchskennzahlentwicklung nach Baualtersklassen. Bauphysik 32 (1), 1-6.

Hardin, W. G. I., Hill, M. D., Hopper, J. J., 2009. Ownership Structure, Property Performance, Multifamily Properties, and REITs. Journal of Real Estate Research 31 (3), 285-306. 
Henderson, J., Ioannides, Y., 1983. A Model of Housing Tenure Choice. The American Economic Review 73 (1), 98-113.

Herzog, J., 1963. Structural Change in the Housebuilding Industry. Land Economics 39 (2), 133-141.

Hesse, M., Preckwinkel, W., 2009. Globalization of the housing industry. Potential for conflicts between tenants and international investors as a result of the privatization of municipal housing estates in Berlin, Germany. Zeitschrift Fur Wirtschaftsgeographie 53 (3), 156-171.

Hyland, M., Lyons, R. C., Lyons, S., 2013. The value of domestic building energy efficiency - evidence from Ireland. Energy Economics 40, 943-952.

Iwaro, J., Mwasha, A., 2010. A review of building energy regulation and policy for energy conservation in developing countries. Energy Policy 38 (12), $7744-7755$.

Iwata, S., Yamaga, H., 2008. Rental externality, tenure security, and housing quality. Journal of Housing Economics 17 (3), 201-211.

Jacobsen, G. D., Kotchen, M. J., 2013. Are building codes effective at saving energy? Evidence from residential billing data in Florida. Review of Economics and Statistics 95 (1), 34-49.

Kinzy, S. A., 1992. An Analysis of the Supply of Housing Characteristics by Builders Within the Rosen Framework. Journal of Urban Economics $32(1), 1-16$.

Klauß, S., Kirchhof, W., Gissel, J., 2009. Katalog regionaltypischer Materialien im Gebäudebestand mit Bezug auf die Baualtersklasse und Ableitung typischer Bauteilaufbauten. Tech. rep., Kassel.

Kok, N., McGraw, M., Quigley, J. M., 2012. The diffusion over time and space of energy efficiency in building. The Annals of Regional Science 48 (2), 124 .

Leth-Petersen, S., Togeby, M., 2001. Demand for space heating in apartment blocks: measuring effects of policy measures aiming at reducing energy consumption. Energy Economics 23 (4), 387-403. 
Maisel, S. J., 1953. Housebuilding in Transition: Based on Studies in the San Francisco Bay Area. Publications. University of California Press.

Malpezzi, S., Shilling, J., 2000. Institutional investors tilt their real estate holdings toward quality, too. Journal of Real Estate Finance and Economics 21 (2), 113-140.

Metcalf, G., Hassett, K., 1999. Measuring the Energy Savings from Home Improvement Investments: Evidence from Monthly Billing Data. Review of Economics and Statistics 81 (3), 516-528.

Michelsen, C., 2009. Energieeffiziente Wohnimmobilien stehen im Osten und Süden der Republik: Ergebnisse des ista-IWH-Energieeffizienzindex. Wirtschaft im Wandel 15 (9), 380-388.

Michelsen, C., Müller-Michelsen, S., 2010. Energieeffizienz im Altbau: Werden die Sanierungspotenziale überschätzt? Ergebnisse auf Grundlage des ista-IWH-Energieeffizienzindex. Wirtschaft im Wandel 16 (9), 447-455.

Myers, D., 2008. Construction Economics: A New Approach. A New Approach. Taylor \& Francis.

Nair, G., Gustavsson, L., Mahapatra, K., 2010. Factors influencing energy efficiency investments in existing Swedish residential buildings. Energy Policy 38 (6), 2956-2963.

OECD, 2003. Environmentally Sustainable Buildings. Organisation for Economic Co-Operation and Development, Paris.

Rehdanz, K., 2007. Determinants of residential space heating expenditures in Germany. Energy Economics 29 (2), 167-182.

Schleich, J., Gruber, E., 2008. Beyond case studies: Barriers to energy efficiency in commerce and the services sector. Energy Economics 30 (2), 449-464.

Schröder, F., Greller, M., Hundt, V., Mundry, B., Papert, O., 2009. Universelle Energiekennzahlen für Deutschland- Teil 1: Differenzierte Kennzahlverteilungen nach Energieträger und wärmetechnischem Sanierungsstand. Bauphysik 31 (6), 393-402. 
Somerville, C., 1999. The Industrial Organization of Housing Supply: Market Activity, Land Supply and the Size of Homebuilder Firms. Real Estate Economics 27 (4), 669-694.

Stevens, B., 1975. Single-Site Economies in the Construction of Multi-Family Housing. Land Economics 51 (1), 50-57.

Veser, J., Thrun, T., Jaedicke, W., 2007. Veränderung der Anbieterstruktur im deutschen Wohnungsmarkt und wohnungspolitische Implikationen. BBSR Forschungen. Bundesamt für Bauwesen und Raumordnung, Bonn.

Williamson, O., 1979. Transaction-Cost Economics - Governance of Contractual Relations. Journal of Law \& Economics 22 (2), 233-261. 